\title{
Understanding Determinants of Individual Intention to Invest in Digital Risky Investment
}

\author{
Willy Abdillah ${ }^{1}{ }^{\bowtie}$, Rika Permata Sari $^{2}$, Ernie Hendrawaty ${ }^{3}$ \\ Faculty of Economics and Business, Universitas Bengkulu, Indonesia ${ }^{1,2}$ \\ Faculty of Economics and Business, Universitas Lampung, Indonesia ${ }^{3}$
}

\begin{tabular}{l} 
Info Article \\
\hline History Article: \\
Received 21 February 2019 \\
Approved 12 August 2019 \\
Published March 2019 \\
\hline Keywords: \\
Emotional Intelligence; Locus of \\
Control; Risk Aversion; Financial \\
Literacy; and Intention to Digital \\
Risky Investment.
\end{tabular}

Risky Investment.

\begin{abstract}
This study examines the effect of emotional intelligence, the locus of control, and risk aversion on intention to invest in digital risky investment with financial literacy as moderating effect. This study uses 98 investors of digital risky investment (such as bitcoin and other crypto currency instruments), distributed by online questionnaire. Data examined using Partial Least Square (PLS) technique. The results show that the emotional intelligence ( $t$-stat 3.057 ), the locus of control ( $t$-stat 3.603) has a positive effect and risk aversion ( $t$-stat -2.287 ) and financial literacy ( $\mathrm{t}$-stat -2.970 ) have a negative effect on intention to a risky investment. However, there is no moderating effect of financial literacy on those direct effects. It indicates that the individual psychological factors are not reinforced or weakened by the level of financial literacy. The implication for stakeholder and further research are discussed.
\end{abstract}

\section{Memahami Faktor Penentu Niat Individu untuk Berinvestasi dalam Investasi Digital Berisiko}

\begin{abstract}
Abstrak
Studi ini menguji pengaruh Kecerdasan Emosional, Lokus Kendali dan Aversi Risiko pada Niat untuk berinvestasi pada investasi digital berisiko, dengan Literasi Keuangan sebagai variabel pemoderasian. Studi ini menggunakan 98 investor investasi digital berisiko (seperti bitcoin dan instrument-instrumen mata uang kripto), yang didistribusi melalui kuesioner online. Data diuji menggunakan Teknik Partial Least Square (PLS). Penelitian menemukan bahwa Kecerdasaan Emosional (t-stat 3.057), Lokus Kendali (t-stat 3.603) berpengaruh positif pada niat berinvestasi digital berisiko, sedangkan Aversi Risiko ( $t$ stat -2.287) dan Literasi Keuangan ( $t$-stat -2.970) berpengaruh negatif. Selain laitu, tidak ditemukan efek pemoderasian Literasi Keuangan pada pengaruh kedua efek langsung tersebut. Hal ini mengindikasi bahwa faktor-faktor psikologis investasi tidak mampu diperkuat atau diperlemah pengaruhnya oleh Literasi Keuangan. Implikasi temuan penelitian bagi pemangku kepentingan dan penelitian selanjutnya, didiskusikan lebih lanjut dalam tulisan ini.
\end{abstract}

JEL Classification: M3,M31 
Willy Abdillah, et al./ Understanding Determinants Of Individual Intention To Invest In Digital Risky....

\section{INTRODUCTION}

Investments always include risk factors (Ehrhardt \& Brigham, 2016). A paradigm mentions that the higher the risk, the higher the potential also profit. This "law" is particularly applicable in emerging market economies, including Indonesia. Investing in Indonesia can be very profitable but also implies more risks than investing in developed countries because Indonesia has certain dynamics and characteristics that can thwart investment and its climate KPMG (2015).

From the data announced by Otoritas Jasa Keuangan (OJK), at the beginning of 2017 there are 200 more illegal investment companies at high risk and harm the public (OJK, 2018). In the first quarter of 2018 , OJK has announced 74 entities suspected of undertaking unlicensed business activities and potentially harming the public. These entities offer different types of investment products ranging from chain-breaking, savings with big prizes, multi-level marketing or MLM, savings and credit cooperatives to online trading, both offline or online platform. In this context, there are still many Indonesians, especially in suburban areas trapped by this illegal investment (OJK, 2018). Therefore, it is an interesting issue to examine individual financial behavior thoroughly.

Previous studies have attempted to explain individual financial behavior by emphasizing the role of demographic factors (age, gender, income, marital status and education level) or socio-economic (Bajtelsmit \& Bernasek, 1996) and personal characteristic factors (characteristics, values, emotions, tolerance to risk) (Larkin et al., 2013). Other factors are the market (such as expected risk, rate of return, transaction costs, and market environment) and other related factors (Pak \& Mahmood, 2015). It could be say that those studies refer to the classical finance paradigm. However, this research refers to the financial behavior about how humans respond and react to existing information and then used to take decisions that can optimize the return on investment decisions by conside- ring the risks that embedded in it (elements of human attitudes and actions are the deciding factor in investing).

To understand the issues related to individual's financial behavior, one must manage is personal finances in one way or another. For example, some people tend to store a lot of information, some want to collect information before doing each purchase, and some people want to follow their instincts. Funfgeld (2009) classifies investors according to their financial attitudes and behaviors. According to Funfgeld (2009) private investors are individuals with a variety of financial practices combined with various levels of experience, anxiety levels and the intention of investing. By doing the classification, then the needs of the invdividu in a group in terms of financial affairs can be studied well according to segment.

There are number of factors that influence the financial decisions of individuals at risk, e.g., personality traits (narcissism, sensation search, or locus of control, and attitudes toward money (Norvilitis et al., 2006). However, there are still many individual characteristics to investigate, such as emotional intelligence (Emotional Intelligence, hereinafter abbreviated as EI). Previously, EI factors were used in risk-taking arrangements in the context of learning, entrepreneurship and health risk-taking (Kamalian et al., 2013), but EI has relatively examined in the context of risky investment, particularly in digital financial instruments. Thus, this study examines the role of EI as determinant of individual intention in digital risky investment.

In addition, the locus of control (LOC) has also been extensively discussed by scientists, particularly in the context of entrepreneurship. LOC and risky decision making are considered as entrepreneurial traits (Thompson, 2009). Previous study also linked the LOC with risky behavior in entrepreneurship and health risk management areas (Aydemir \& Aren, 2017). In terms of financial behavior, it is known that the LOC moderates the relationship between the financial literacy ability and the behavior of financial management accountants (Perry \& 
Morris, 2005). In addition, the LOC has a positive influence on financial risk tolerance (Grable, 2000). However, previous studies relatively limited examined LOC in the context of risky investment. Therefore, this study used LOC as predictor of individual intention in digital risky investment.

This study also examines risk-aversion (RA) as a predictor of individual intention in digital risky investment. RA is implicitly sourced from Theory of Reasoned Action (Ajzen \& Fishbein, 1977) and Theory of Planned Behavior (Ajzen, 1991) which suggests that RA has the potential to encourage behavior through intention to behave. Previous studies have revealed that risk-taking by a person may be different from that observed due to several factors, such as the problem-solving process in information processing and belief (Schoemaker, 1993). The problem of risk perception framing affects risky decision making. Thus, RA becomes relevant to be studied as a determinant of digital risky investment behavior (Sitkin and Weingart, 1995).

On the other hand, financial literacy is found to have a positive impact on various financial behaviors (Aren \& Aydemir, 2014). By studying the effects of moderation of financial literacy allegedly can change the relationship between individual factors and risky investment behavior. Therefore, this study aims to examine how emotional factors and attitudes interact with financial knowledge (cognitive factors) that attract the attention of digital risky investments.

EI and LOC have a positive impact on financial decision making, while RA is generally negative. Although financial literacy has no direct effect on risky financial behavior, it has an important role as a moderator variable, interacting with the LOC (Aydemir \& Aren, 2017).

Risky investments are used to define financial instruments other than investments that have nominal returns. With this kind of investment, investors do not know how much they should earn and may also lose the money invested. Digital risky investment intentions are a concept to illustrate how many individuals want to invest in alternative investments. Intrinsic risk can cause people's attitudes to differ from the observed risk-taking behavior (Schoemaker, 1993). This risk-taking attitude can be influenced by genetic factors (Kuhnen \& Chiao, 2009).

On the other hand, Wang et al. (2011) found that individuals perceived more known instruments, considered familiar and more easily understood, as less risky instruments. Similarly, Vlaev et al. (2009) states that the level of financial knowledge has an influence on the assessment of the nature of the investment, risky or not. In general, the link between risk taking and risk behavior has a long history based on the references of the research group (Weber \& Milliman, 1997; Cooper \& Faseruk, 2011).

\section{Hypothesis Development}

\section{The Effect of Emotional Intelligence (EI) on Digital Risky Investment Intention}

EI as the ability to self-monitor with the feelings of others and emotions (Salovey \& Mayer, 1990). This model is approaching the concept as a series of emotional abilities. In this context, the EI is in four dimensions, namely understanding emotions, managing oneself and the emotions of others, and using them in action.

Although emotions and rationality have been considered as oxymoronic concepts in the context of decision-making, recent research has confirmed that emotions can increase output and decision processes (Rausch et al., 2011). As an integral part of the rational process, decision making will flourish at a higher of EI (Humphrey et al., 2007). Especially in uncertain conditions, risk-taking is necessary for decision makers. Under these circumstances, what will happen, is predicted through the possibility of anxiety that can arise. These negative effects can lead to poor decision making. For that, EI can direct people who were previously 
Willy Abdillah, et al./ Understanding Determinants Of Individual Intention To Invest In Digital Risky....

part of decision making by skillfully managing mood (Chapman, 2006).

Chapman (2006) also discusses that the introduction and understanding of emotions will influence the behavior of risk choices by reducing avoidable errors. As a result, emotional ability is considered important in risk-making decisions. Indeed, studies in other risk settings, such as leadership (Batool, 2013), entrepreneurship (Foo, 2011; Kamalian et al., 2011), learning (Humphrey et al., 2007) and organizational change (Vakola et al., 2004), have uncovered EI as an important factor in decision making.

There are currently many economic and financial studies that have important differences in the research model (Sjöberg \& Engelberg, 2009; Yip \& Côté, 2013). However, there are no studies that explicitly examine financial behavior. Therefore, it is necessary to review the EI model on risk-based IT investment decisions.

Demaree et al. (2008) has emphasized that emotional reactions can affect self-control behavior. In addition, Olson (2006) argues that an assessment strongly related to the classical financial paradigm can have an impact on financial behavior. In addition, Satterfield (1998) has discussed that individual cognitive and affective states may be associated with deviant behavior. Ameriks et al. (2009) has shown that higher financial performance is associated with higher intellectual acumen. Precisely, individuals who have emotional intelligence, able to overcome the negative impacts arising from risky decisions well. That is, EI encourages individuals to make risky investments easily by generating optimism and confidence (Ebrahimi \& Yarahmadzehi, 2015). These optimistic and confident individuals are more likely to invest in risky alternatives because their emotions can shape their risk perceptions of risky alternative investments (Foo, 2011). Thus, the hypothesis tested in this study is as follows.

$\mathrm{H1}$ : Emotional intelligence affects digital risky investment intention.

\section{The Effect of Risk Aversion on Digital Risky Investment Intention}

The Risk aversion effect was first presented by Kahneman and Tversky (1979) as part of the prospect theory, in the domain of behavioral economics. The reflection effect is a pattern identified from the opposite preference between a negative outlook compared to a positive outlook. According to this effect, people tend to avoid risks under the profit domain, and to seek risk under the domain of loss. That is, no risk aversion is expected to occur under the domain of loss. For example, in the profit domain, most people prefer a certain profit of 3000 , rather than a 4000 profit with 80 percent risk. When posing the same problem under the domain loss, most people prefer a loss of 4000 with a probability of 80 percent, during the loss of 3000 .

In the field of economy and finance, risk aversion is human behavior (especially consumers and investors), when exposed to uncertainty, regarding to reduce the uncertainty. This indicates a person's doubt to approve a situation with unknown results than other situations with more predictable results but may decrease expected payoff. For example, a risk-averse investor may choose to put his money into a lowinterest but guaranteed bank account instead of a stock that may have a high expected rate of return, but also involve the possibility of a loss of value.

RA in the context of risky investments can generally be recognized as an attitude that reflects a level when an individual avoids taking risks in general. This attitude, along with subjective norms, creates the possibility of risky behavior (Ajzen \& Fishbein, 1977; Ajzen, 2002).

McCarty (2000) posits two types of risk taking, namely intrinsic risk taking and self-preservation behavior. The personal mindset first thought of by others, will make people think about the circumstances that change according to changing conditions. However, Peterson (2011) mentions the weak relationship of genetic characteristics with risk taking. Weber et 
al. (2002) have demonstrated that risk taking applies certain domains. That is, individuals do not consistently seek risk aversion (Lian et al., 2018). This study argues that individual who has risk averse will have lower intention to invest in digital risky investment. Thus, the hypothesis tested in this study is as follows.

H2: Risk Aversion affects on digital risky investment intention.

\section{The Effect of Locus of Control (LOC) on Di- gital Risky Investment Intention}

LOC is the individual's control of the job and the belief in self-efficacy. LOC is divided into two, namely the internal control locus that characterizes a person having confidence to answer for work behavior in the organization. External control characterizes individuals who believe that work behavior and task success are more due to factors outside the self, such as an organization.

The concept of LOC was first proposed by Rotter (1966), a social learning theorist. LOC is one of the personality variables defined as individual beliefs in self-control. Meanwhile, Robbins and Judge (2009) define LOC as the level of individual confidence in self-determination. The internal LOC is the control over whatever happens to yourself, while the external is controlled by forces from outside the self, such as luck and opportunity.

People feel different advantages or disadvantages due to factors outside of action or control (Ajzen, 2002), the effect of reinforcement on behavior may indicate different levels of inter-individual rewards derived from behavior (Rotter, 1966). Thus, if the individual finds reinforcement as a result of the action, then the individual has an internal LOC. On the contrary, if the individual finds a reinforcement as a result of an act that can not be controlled on its own, then the individual has an external LOC. This construct when tested shows a consistent difference between individuals. Thus, the internal-external LOC as a personality variable has been used in many studies.
Particularly in the entrepreneurial literature, researchers have linked the internal LOC and risk-taking as an entrepreneurial characteristic (Schjoedt \& Shaver, 2012). Similarly, previous studies have found strong links between LOC and risk behavior (Crisp \& Barber, 1995; Carpentier et al., 2014).

These earlier studies were also examined in the context of financial behavior. Duxbury et al. (1996) have found that informal investors in Canada have higher scores in internal assessments. In addition to financial and gender literacy, Grable and Joo (2000) found that LOC is one of the determinants of financial risk tolerance. There was direct and indirect LOC effects on responsible financial behavior (Perry \& Morris, 2005). A positive relationship between LOC, financial literacy, and behavior in financial decision-making (Brounen et al., 2016). This finding has also been supported that finds an external LOC behavioral relationship with the decision to borrow (Cobb-Clark et al., 2016; \& McNair et al., 2016).

This study argues that the LOC directly affects the intentions of IT-based risky investment decisions. Therefore, the hypothesis tested in this study is as follows.

H3: Locus of control affects IT-based risky investments intention.

\section{The Effect of Financial Literacy (FL) on IT Risk Based Investment Decisions}

Level of financial literacy plays a very important role in influencing the willingness to accept risks in relation to certain financial investments (Pak \& Mahmood, 2015). Generally, investors are less interested in doing a less understood transactions (Anbar \& Melek, 2010). The results showed that respondents with higher levels of financial knowledge showed higher risk tolerance as well (Grable \& Joo, 2000).

Conversely, there is research that finds the negative effects of financial literacy on risky investment intentions. The cause of financial literacy has an inhibit or inhibiting effect, ie when individuals have high literacy rates, it can pre- 
Willy Abdillah, et al./ Understanding Determinants Of Individual Intention To Invest In Digital Risky....

vent a person's intentions for risky investments. It also indicates that higher knowledge can make the decision-making process more complicated so that the probability of investment decision decision is lower risk.

Based on the results of discussion showing the causal relationship between the level of financial literacy with the level of financial risk tolerance that the result of conflict, the hypothesis proposed in this study are:

H4: Financial Literacy (FL) affects the IT Risk Based Investment Risk Decision

\section{Moderating Effect of Financial Literacy on the Effect of Emotional Intelligence (EI), Risk Aversion (RA) and Locus of Control (LC) on IT-Based Risky Investment Intention}

Although previous literature is limited in explaining financial literacy, Huston (2010) describe FL as a person's ability to understand and utilize financial concepts. FL is different from the level of formal education. Individuals who have knowledge of financial concepts, such as calculating the value of money, stocks, bonds, and special policies are considered to have FL, even though the individual has no formal education.

FL as the ability to understand financial conditions, financial concepts and alter that knowledge appropriately into behavior (Huston, 2010). The unconsciousness of people about basic finance topics, such as compound interest causing people to think saving will result in considerable returns (Akerlof and Shiller, 2010). Conversely, individuals who have FL can explicitly distinguish various aspects of finance and economics. FL encourages individuals actively and responsibly for financial planning, especially when there is a global financial crisis (Robb \& Woodyard, 2011).

Furthermore, previous studies have also found the differences FL effect in risk perceptions (Diacon, 2004), i.e individuals who have FL prefer riskier alternatives than ordinary individuals. FL is also found to have a positive impact on portfolio diversification (Guiso \&
Jappelli, 2008), higher stock participation (Van Rooij et al., 2007), and readiness for early retirement (Lusardi \& Mitchelli, 2007). This study argues that individual who have higher FL will intent to invest in digital risky investment because they are knowledgeable and have preferred investment information. Thus, FL will moderate the effect EI, LOC and RA on digital intention of risky investment. The hypotheses tested in this study are as follows.

H5: The effect of EI on digital risky investments is weaker for higher financial literacy groups.

H6: The effect of LOC on digital risky investments is weaker for higher financial literacy groups.

H7: The effect of RA on digital risky investments is weaker for higher financial literacy groups.

The proposed research models tested in this study are shown in Figure 1.

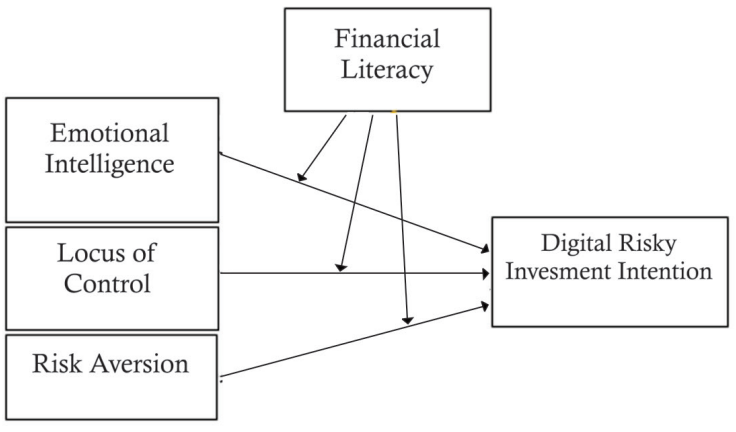

Figure 1. Research Model

\section{METHOD}

Our study empoys quantitative approach with survey as a research design. The variables tested in this research are independent variable, dependent variable and moderation variable.

Independent variables in this study consisted of emotional intelligence, locus of control, risk aversion and financial literacy. Dependent variable is an IT-based risk investment intent. Moderate variables are variables that 
strengthen or weaken the influence of independent variables on the dependent variable. In this study the moderation variable is the level of financial literacy.

Population in this study are investors who have invested in digital risky financial instruments, such as forex, bitcoin, and others. Due to lack of sampling frame, this study used nonprobability sampling method. The sample size is determined based on the sample adequacy requirements determined by a statistical tool, which is 10 times the number of variables for linear regression (Hair et al., 2006). For that, this study used 98 respondents. Sampling technique in this research is purposive sampling with criterion is investor who have invested at least last year, aged 18 years and above, and preferably have income on regular basis.

This study uses primary data. Techniques of collecting data using questionnaires with 7 points likert scale, ranging from strongly disagree to strongly agree. All data were tested using the Partial Least Square (PLS) method due to our research objective is to examine the effect determinants on criterion (predictive model). Testing phase consists of evaluation of measurement model for construct validity and reliability, and evaluation of structural model for hypothesis testing.

\section{RESULT AND DISCUSSION}

The research data was collected by distributing questionnaires to the respondents by using online questionnaire method. The research data was collected from May 25, 2018 to June 02,2018 . With a total of 98 respondents.

The characteristics of respondents in this study are shown in Table 1 . The general cha-

Table 1. Characteristics of Respondents

\begin{tabular}{llll}
\hline Characteristics & Interval & Respondent & Percentage (\%) \\
\hline Gender & Male & 71 & 72 \\
& Female & 27 & 28 \\
Age & $\Sigma$ & 98 & 100 \\
& $17-25$ Years & 48 & 49 \\
Education & 26-50 Years & 50 & 51 \\
& $>50$ Years & 0 & 0 \\
& $\Sigma$ & 98 & 100 \\
& Postgraduate & 11 & 12 \\
Never of not invest & Undergraduate & 34 & 35 \\
& Diploma & 23 & 23 \\
Type of invest & Higher Education & 30 & 30 \\
& $\Sigma$ & 98 & 100 \\
& Ever & 40 & 41 \\
& Never & 58 & 59 \\
& $\Sigma$ & 98 & 100 \\
& Forex & 18 & 18 \\
& Bitcoin & 39 & 40 \\
Invest duration & Others & 41 & 42 \\
& $\Sigma$ & 98 & 100 \\
& Less than 1 year & 57 & 58 \\
& $1-2$ years & 18 & 18 \\
& More than 2 years & 23 & 24 \\
& $\Sigma$ & 98 & 100 \\
\hline
\end{tabular}


Willy Abdillah, et al./ Understanding Determinants Of Individual Intention To Invest In Digital Risky....

racteristics of respondents in this study are illustrated by age, gender, education, never or not investing, investment type and investment duration.

Table 1 shows that by age, the mean age of respondents is 28 years (rounding up). This indicates that the respondents included in the category of adult and productive age. Based on sex, the number of respondents in this study the number of men more than women so this indicates a tendency of male preference to make risky investments. Based on the level of education, most respondents are educated undergraduate level. This indicates that investors in general have had a sufficient level of formal education, although it has not fully reflected the FL. Most of the respondents are investors with long-term investment of less than one year $(<1$ year) with selected investment type is combination (forex, bitcoin, and others). This indicates the level of investment experience is still quite low, but the investment risk portfolio is quite dispersed.

\section{Evaluation of Measurement Models}

Testing the validity and reliability in this study using the Partial Least Square (PLS) measurement model. Convergent validity is assessed by output from outer loading (see annex) and Average Variance Extracted (AVE) (Abdillah \& Hartono, 2015). Based on the results of the PLS algorithm test in Table 2 shows that all model indicators with outer loading are greater than 0.50 (unless EI5 and EI15 are maintained because the reliability is still met), so it can be concluded that the indicator meets the validity criteria. Like wise with AVE parameters, it appears that all constructs have met these criteria.

Discriminant validity tests are based on cross loading measurements with their constructs. The indicator is said to be discri-

Table 2. Measurement Model Overview

\begin{tabular}{llllll}
\hline Construct & Indicators & AVE & Composite Reliability & Cronbachs Alpha & R-square \\
\hline EI & 0.692609 & 0.418736 & 0.805507 & 0.752300 \\
& 0.672893 & & & \\
& 0.442958 & & & \\
& 0.835697 & & & \\
& 0.669607 & & & \\
& 0.486775 & & & 0.721904 \\
LC & 0.979380 & 0.738717 & 0.846759 & & \\
& 0.719894 & & & 0.721744 \\
FL & 0.785402 & 0.458342 & 0.807504 & & \\
& 0.637005 & & & & \\
& 0.700242 & & & 0.300678 \\
& 0.628205 & & & & \\
DRII & 0.619758 & & & & \\
& 0.817521 & 0.700601 & 0.902638 & & \\
& 0.705566 & & & 0.653339 & \\
RA & 0.903812 & & & & \\
& 0.905189 & & & & \\
& 0.932479 & 0.702796 & 0.823380 & & \\
\hline
\end{tabular}


minantly valid if the value of cross loading more than 0.70 in one variable Abdillah and Hartono (2015). Based on the cross-loading test results in Table 3, all indicators in each latent construct meet the criteria of discriminant validity.
Hartono, 2015). Based on the reliability test in Table 2, all constructs are considered reliable. After meeting the required criteria of validity and reliability, we continue with structural analysis.

Tabel 3. Cross Loadings

\begin{tabular}{llllrr}
\hline \multicolumn{1}{c}{ Indicator } & EI & LC & FL & \multicolumn{1}{c}{ DRII } & RA \\
\hline EI13 & 0.692609 & 0.002835 & 0.030644 & 0.290622 & 0.110462 \\
EI14 & 0.672893 & -0.056094 & -0.061079 & 0.055892 & -0.092918 \\
EI15 & 0.442958 & 0.025321 & -0.083620 & 0.043148 & -0.083753 \\
EI3 & 0.835697 & -0.084535 & -0.071225 & 0.277337 & -0.263554 \\
EI4 & 0.669607 & -0.157469 & -0.010103 & 0.147911 & -0.150042 \\
EI5 & 0.486775 & 0.107556 & -0.019738 & 0.115152 & -0.129859 \\
LC1 & 0.047819 & 0.979380 & 0.138132 & 0.272868 & 0.208301 \\
LC6 & -0.389589 & 0.719894 & 0.117881 & 0.079423 & 0.285496 \\
FL4 & 0.016790 & 0.029109 & 0.785402 & -0.206192 & 0.280973 \\
FL6 & -0.111335 & 0.128900 & 0.637005 & -0.093499 & 0.240027 \\
FL7 & -0.154641 & 0.216208 & 0.700242 & -0.123733 & 0.178914 \\
FL8 & 0.065878 & 0.093373 & 0.628205 & -0.190485 & 0.102989 \\
FL9 & -0.033870 & 0.081252 & 0.619758 & -0.062724 & 0.155087 \\
NI1 & 0.190213 & 0.140229 & -0.183424 & 0.817521 & -0.265940 \\
NI2 & 0.402909 & 0.237187 & -0.125652 & 0.705566 & -0.164962 \\
NI3 & 0.240244 & 0.216747 & -0.207359 & 0.903812 & -0.267723 \\
NI4 & 0.194692 & 0.225117 & -0.246575 & 0.905189 & -0.236966 \\
RA1 & -0.136228 & 0.162073 & 0.269907 & -0.287698 & 0.932479 \\
RA7 & -0.078897 & 0.304797 & 0.194733 & -0.152575 & 0.732170 \\
\hline
\end{tabular}

Moreover, in the discriminant validity test that shown in Table 4, we test whether the instruments used in generating the constructs are related. We insert the value of square root AVE (the bold number) from each construct and further compare it with the inter-latent correlation among construct. In Table 4, the square root AVE value is higher than the inter-latent correlation among construct $(\sqrt{ }$ AVE $>$ correlation value).

\section{Evaluation of Structural Model}

The structural model evaluation is done by evaluating the value of path coefficients or $t$-values of each path for significance test between constructs in structural model and RSquare for dependent constructs. The value of path coefficient or inner model shows the level of significance in hypothesis testing (Abdillah \& Hartono, 2015). Table 2 shows that this rese-

Table 4. Discriminant validity

\begin{tabular}{llllll}
\hline Variable & EI & FL & LC & DRII & RA \\
\hline EI & $\mathbf{0 . 6 4}$ & & & & \\
FL & $-0.036^{* *}$ & $\mathbf{0 . 8 5}$ & & & \\
LC & $-0.022^{* *}$ & $0.145^{* *}$ & $\mathbf{0 . 6 7}$ & & \\
DRII & $0.324^{* *}$ & $-0.229^{* *}$ & $0.249^{* *}$ & $\mathbf{0 . 8 3}$ & \\
RA & $-0.117^{* *}$ & $0.282^{* *}$ & $0.245^{* *}$ & $-0.279^{* *}$ & $\mathbf{0 . 8 3}$ \\
\hline
\end{tabular}

Additionally, this study also tested the reliability. The construct is considered reliable if the rule of thumb cronbach alpha or composite reliability is greater than 0.6 (Abdillah \& arch model has moderate effect size (Average R Square 0.3) (Chin, 2010).

Hypothesis testing is done to see the relationship between independent variables, name- 
Willy Abdillah, et al./ Understanding Determinants Of Individual Intention To Invest In Digital Risky....

ly Emotional Intelligence (EI), Locus of control (LC), Risk Aversion (RA) to dependent variable, ie Intention to Invest (NI), with Financial Literacy level (FL) as moderating variables. Hypothesis testing was done by inner model test with $95 \%$ confidence level and error in 5\% analysis. The research model in hypothesis testing consists of two research models, namely the direct effect structural model and the moderate effect moderation model. By using Bootstrapping method in SmartPLS 2.0 software, standard error can be obtained, path coefficients $(\beta)$, and T-Statistics. With this technique, researchers can assess the statistical significance of the research model by testing the hypotheses for each relationship path.

To analyze the relationship of each variable or testing the research hypothesis is done by comparing the $\mathrm{T}$-statistic value. If the value of $\mathrm{T}$ statistic $\geq 1.96$ then there is a significant influence between the variables tested. Ouput of the Bootstrapping method for hypothesis testing of direct and moderate effect structural models is presented in Table 5.

Tabel 5. Structural Model Results
2008; Lusardi \& Mitchelli, 2007; Van Rooij et al., 2007).

This study found that emotional intelligence affects digital risky investment intention. This finding explains that the higher the emotional control within one's personality is increasingly influencing the intention to risk investments based on information technology. Factors causing the influence of emotional intelligence on intentions for information technology-based investments, due to higher emotional capabilities that allow individuals to feel more confident and courageous thus taking the decision to take risky investments based on information technology. When the individual feels understanding of the emotions that occur in him, will appear confidence and hope that in facing a decision they can solve problems that will arise later. This causes a person who has a high emotional intelligence will be easier to decide.

This finding is consistent with Aydemir and Aren (2017) who found that superior emotional skills had a positive effect on risky investment intentions. Ciarrochi et al. (2001) have

\begin{tabular}{llrrrrrr}
\hline $\begin{array}{l}\text { Hypo- } \\
\text { theses }\end{array}$ & Path & $\begin{array}{l}\text { Original } \\
\text { Sample (O) }\end{array}$ & $\begin{array}{l}\text { Sample } \\
\text { Mean (M) }\end{array}$ & $\begin{array}{l}\text { Standard } \\
\text { Deviation } \\
\text { (STDEV) }\end{array}$ & $\begin{array}{l}\text { Standard } \\
\text { Error } \\
\text { (STERR) }\end{array}$ & $\begin{array}{l}\text { T Statistics } \\
(\mid \text { O/STER } \mid)\end{array}$ & p-value \\
\hline 1 & EI -> NI & 0.289 & 0.324 & 0.094 & 0.094 & 3.057 & 0.001 \\
2 & LC - NI & 0.360 & 0.340 & 0.099 & 0.099 & 3.603 & 0.001 \\
3 & FL - > NI & -0.194 & -0.235 & 0.084 & 0.084 & 2.287 & 0.001 \\
4 & RA -> NI & -0.274 & -0.288 & 0.092 & 0.092 & 2.970 & 0.001 \\
5 & EI*FL -> NI & -0.375 & 0.022 & 0.478 & 0.478 & 0.784 & 0.422 \\
6 & LC * FL -> NI & -0.323 & -0.059 & 0.431 & 0.431 & 0.748 & 0.420 \\
7 & RA $^{*}$ FL -> NI & -0.451 & -0.395 & 0.406 & 0.406 & 1.108 & 0.872 \\
\hline
\end{tabular}

Based on Table 5, EI and LOC have a positive effect, while RA and FL negatively affect on digital risky investment intention. Thus, all direct effect hypotheses are accepted and support risk behavioral investment decision theories. However, moderation effect testing did not find any moderating effect of FL on the effect of EI, LOC, and RA on digital risky investment intention. These findings do not support previous FL studies (Diacon, 2004; Guiso \& Jappelli, found a positive relationship between emotional intelligence as measured by self-esteem and anxiety, with investment decisions. Thus, individuals with high emotional intelligence are more likely to have high self-esteem and low anxiety, making it emotionally easy to make risky investments.

In addition, ease of information that offers different types of investments in information technology systems, is also suspected to be the 
reason investors prefer to invest digitally. The availability of such information can suppress the emotion in making the decision to choose to invest and take risks that exist.

This study also found that Locus of control has positive effect on digitalbased risky investment intention. This finding explains the greater the individual's control over actions or decisions will increase digital investment intention. The cause of the Locus of control factor for digital risky investment intention is the level of self-control that convinces individuals to be able to profit from information technology-based investments even though it is likely to be controlled by outside forces.

Causes of success and failure Locus of control may be affected by ability and effort (internal LOC) and difficulties and fate (external LOC). Individuals who have control over their ability and effort will have greater motivation and satisfaction of profit generated from digital investment. Meanwhile, individuals with external LOC tend to find difficulty and resigned to the fate of the investment. Individuals tend to believe that fate, opportunity, luck, or other people's behavior determine the outcome.

This finding has similarity with Aydemir and Aren (2014) which empirically observe the positive effect of LOC on risky investment intention. However, this study does not examine differences in the effect of internal and external LOCs on digital risky investment intention. If Indonesian investors are more likely to have external LOCs, it has the potential to increase risky investment intentions as a result of low levels of confidence and self-control.

The result of the third hypothesis testing, finding Risk Aversion negatively affect on digital risky investment intention. It indicates that individual's attitude to avoid risk in a state of uncertainty will make the lower the intention to invest. This is due to the type of digital risky investments such as Bitcoin, Forex, Index or others, demanding individuals to have high courage or risk takers.

In an investment, the higher the risk the higher the return. When individuals are risk aversion individuals tend to avoid such investments because individuals perceive better low risk investments even if the returns are also low. This is an explanation of why the number of domestic investors in the capital market society in Indonesia is still low. Although KSEI reported an increase in the number of Indonesian capital market investors throughout 2017, there were $1,118,913$ people as of December 20, 2017 or increase of 25.24 percent compared to last year's position, this figure is still very small compared to the current Indonesian population ( 0.4 percent).

Furthermore, the study also found a negative effect of financial literacy on digital risky investment intention. This indicates that financial literacy has an inhibitory effect, when individuals have high literacy rates, it can prevent a person's intentions for digital risky investments. It also indicates that higher knowledge can make the decision-making process more complicated so that the probability of risky investment intention is lower. However, this study found that financial literacy does not play a role in strengthening or weakening the effect of IE, LOC and AC on risky investments intention. Thus hypothesis 5, hypothesis 6 and hypothesis 7 are rejected.

The cause of the rejection of these three hypotheses is the direct negative effect of inhibitory financial literacy. When individuals have limited information processing capabilities over much of their knowledge, individuals tend to be reluctant to make investment decisions. Therefore, consultants or financial institutions should consider this issue to intensively provide appropriate information according to the needs of investors without incriminating the investment decision-making process from the data and information provided.

\section{CONCLUSION AND RECOMMENDATION}

This study examines determinants of individual intentions for risky investments based on information technology. This research found that emotional intelligence and locus of control 
Willy Abdillah, et al./ Understanding Determinants Of Individual Intention To Invest In Digital Risky....

have a positive effect on digital risky investment intention, but risk aversion and financial literacy have negative effect. However, financial literacy does not moderate the effect of emotional intelligence, locus of control, and risk aversion on digital risky investment intention.

The existence of the influence of motional intelligence, locus of control and risk aversion on digital risky investment intention indicates that psychological factors that are relatively neglected by classical finance can explain financial behavior. Microeconomically, financial intermediaries should emphasize individual factors to ensure more investment funds for entry into their systems. For example, consultants or institutions may direct individual investors to alternative investments tailored to their individual differences. Therefore, describing an emotionally-based individual on finance can be something that can be done in the future.

There is no moderation of financial literacy is due to a negative direct impact on financial literacy on digital risky investment intention. It indicates that the individual psychological factors are not reinforced or weakened by the level of financial literacy. Therefore, consultants or financial institutions, can take advantage of the role of psychological factors, namely emotional factors to motivate investors because it is more reliable than giving investors more financial information because the more knowledgeable and financial information obtained by investors, will further hamper investors to process complex investment decision making.

\section{REFERENCES}

Abdillah, W., \& Hartono, J. (2015). Partial Least Square (PLS): Alternatif Structural Equation Modeling (SEM) dalam Penelitian Bisnis. Yogyakarta: Penerbit Andi.

Ajzen, I. (1991). The Theory of Planned Behavior. Organizational Behavior Human Decision Processes, 50(2), 179-211.

Ajzen, I. (2002). Perceived Behavioral Control, SelfEfficacy, Locus of Control, and the Theory of Planned Behavior. Journal of Applied Social Psychology, 32(4), 665-683.
Ajzen, I., \& Fishbein, M. (1977). Attitude-Behavior Relations: a Theoretical Analysis and Review of Empirical Research. Psychological Bulletin, 84(5), 888.

Akerlof, G. A., Shiller, R. J., Domaniç, N., \& Konyar, L. (2010). Hayvansal Güdüler: İnsan Psikolojisi Ekonomiyi Nasıl Yönlendirir ve Küresel Kapitalizm Için Niçin Onemlidir: Scala Yayıncılık.

Ameriks, J., Wranik, T., \& Salovey, P. (2009). Emotional Intelligence and Investor Behavior: Research Foundation of CFA Institute Charlottesville, VA.

Anbar, A., \& Melek, E. J. E. A. B. D. (2010). An Empirical Investigation for Determining of the Relation between Personal Financial Risk Tolerance and Demographic Characteristic. Ege Akademik Bakış Dergis, 10(2), 503-522.

Aren, S., \& Aydemir, S. D. J. J. O. G. S. M. (2014). Some Considerations on Emotional Intelligence. Journal of Global Strategic Management, 15(2), 49-56.

Bajtelsmit, V. L., \& Bernasek, A. (1996). Why do Women Invest Differently than Men?. Financial Counseling, 7.

Batool, B. F. (2013). Emotional Intelligence and Effective Leadership. Journal of Business Studies Quarterly, 4(3), 84.

Brounen, D., Koedijk, K. G., \& Pownall, R. A. (2016). Household Financial Planning and Savings Behavior. Journal of International Money Finance, 69, 95-107.

Carpentier, A., Brijs, K., Declercq, K., Brijs, T., Daniels, S., Wets, G., \& Prevention. (2014). The Effect of Family Climate on Risky Driving of Young Novices: the Moderating Role of Attitude and Locus of Control. Accident Analysis, 73, 53-64.

Chapman, J. (2006). Anxiety and Defective Decision Making: an Elaboration of the Groupthink Model. Management Decision, 44(10), 1391-1404.

Chin, W. W. (2010). How to Write up and Report PLS Analyses, Handbook of Partial Least Squares: 655-690: Springer.

Ciarrochi, J., Chan, A. Y., \& Bajgar, J. (2001). Measuring Emotional Intelligence in Adolescents. Personality Individual Differences, 31(7), 1105-1119.

Cobb-Clark, D. A., Kassenboehmer, S. C., Sinning, M. G., \& Finance. (2016). Locus of Control and Savings. Journal of Banking, 73, 113-130. 
Cooper, T., \& Faseruk, A. (2011). Strategic Risk, Risk Perception, and Risk Behavior: MetaAnalysis. Journal of Financial Management Analysis, 24(2).

Crisp, B. R., \& Barber, J. G. (1995). The Effect of Locus of Control on the Association between Risk Perception and Sexual Risk-Taking. Personality Individual Differences, 19(6), 841845.

Demaree, H. A., DeDonno, M. A., Burns, K. J., \& Everhart, D. E. (2008). You Bet: How Personality Differences Affect Risk-Taking Preferences. Personality Individual Differences, 44(7), 1484-1494.

Diacon, S. (2004). Investment Risk Perceptions: Do Consumers and Advisers Agree?. International Journal of Bank Marketing, 22(3), 180-199.

Dinç Aydemir, S., \& Aren, S. (2017). Do the Effects of Individual Factors on Financial Risk-Taking Behavior Diversify with Financial Literacy?. Kybernetes, 46(10), 1706-1734.

Duxbury, L., Haines, G., \& Riding, A. (1996). A Personality Profile of Canadian Informal Investors. Journal of Small Business Management, 34(2), 44.

Ebrahimi, M. R., \& Yarahmadzehi, N. (2015). Does Emotional Intelligence have Anything to do with Risk-Taking among Iranian EFL Learners?. Theory Practice in Language Studies, 5(10), 2029-2036.

Ehrhardt, M. C., \& Brigham, E. F. (2016). Corporate Finance: a Focused Approach. Cengage Learning.

Foo, M. D. (2011). Emotions and Entrepreneurial Opportunity Evaluation. Entrepreneurship Theory Practice, 35(2), 375-393.

Fünfgeld, B., \& Wang, M. (2009). Attitudes and Behaviour in Everyday Finance: Evidence from Switzerland. International Journal of Bank Marketing, 27(2), 108-128.

Grable, J. E. (2000). Financial Risk Tolerance and Additional Factors that Affect Risk Taking in Everyday Money Matters. Journal of Business Psychology, 14(4), 625-630.

Grable, J. E., \& Joo, S.-H. (2000). A Cross-Disciplinary Examination of Financial Risk Tolerance. Consumer Interests Annual, 46, 151-157.

Guiso, L., \& Jappelli, T. (2008). Financial Literacy and Portfolio Diversification, European University Institute. Economics Working Papers.
Hair, J. F., Black, W. C., Babin, B. J., Anderson, R. E., \& Tatham, R. L. (2006). Multivariate Data Analysis (Vol. 6): Upper Saddle River, NJ: Pearson Prentice Hall.

Humphrey, N., Curran, A., Morris, E., Farrell, P., \& Woods, K. (2007). Emotional Intelligence and Education: a Critical Review. Educational Psychology, 27(2), 235-254.

Huston, S. J. (2010). Measuring Financial Literacy. Journal of Consumer Affairs, 44(2), 296-316.

Kahneman, D., \& Tversky, A. (1979). Prospect Theory: an Analysis of Decision under Risk. Econometrica, 47(2), 363-391.

Kamalian, A., Yaghoubi, N., \& Poori, M. (2011). Emotional Intelligence and Corporate Entrepreneurship: an Empirical Study. Journal of Basic Applied Scientific Research, 1(6), 471-478.

KPMG. (2015). Investing in Indonesia.

Kuhnen, C. M., \& Chiao, J. Y. (2009). Genetic Determinants of Financial Risk Taking. Plos One, 4(2): e4362.

Larkin, C., Lucey, B. M., \& Mulholland, M. (2013). Risk Tolerance and Demographic Characteristics: Preliminary Irish Evidence. Financial Services Review, 22(1).

Lian, C., Ma, Y., \& Wang, C. (2018). Low Interest Rates and Risk-Taking: Evidence from Individual Investment Decisions. The Review of Financial Studies, 32(6), 2107-2148.

Lusardi, A., \& Mitchelli, O. S. (2007). Financial Literacy and Retirement Preparedness: Evidence and Implications for Financial Education. Business Economics, 42(1), 35-44.

McCarthy, B. (2000). Researching the Dynamics of Risk-Taking and Social Learning: an Exploratory Sstudy of Irish Entrepreneurs. Irish Marketing Review, 13, 46-57.

McNair, S., Summers, B., de Bruin, W. B., \& Ranyard, R. (2016). Individual-Level Factors Predicting Consumer Financial Behavior at a Time of High Pressure. Personality Individual Differences, 99, 211-216.

Norvilitis, J. M., Merwin, M. M., Osberg, T. M., Roehling, P. V., Young, P., \& Kamas, M. M. (2006). Personality Factors, Money Attitudes, Financial Knowledge, and CreditCard Debt in College Students 1. Journal of Applied Social Psychology, 36(6):,13951413.

OJK. (2018). Laporan Triwulan I. 
Willy Abdillah, et al./ Understanding Determinants Of Individual Intention To Invest In Digital Risky....

Olson, K. R. (2006). A Literature Review of Social Mood. Journal of Behavioral Finance, 7(4), 193-203.

Pak, O., \& Mahmood, M. (2015). Impact of Personality on Risk Tolerance and Investment Decisions: a Study on Potential Investors of Kazakhstan. International Journal of Commerce, 25(4), 370-384.

Perry, V. G., \& Morris, M. D. (2005). Who is in Control? The Role of Self-Perception, Knowledge, and Income in Explaining Consumer Financial Behavior. Journal of Consumer Affairs, 39(2), 299-313.

Peterson, R. L. (2011). Inside the investor's brain: the power of mind over money: John Wiley \& Sons.

Rausch, E., Hess, J. D., \& Bacigalupo, A. C. 2011. Enhancing Decisions and Decision-making Processes through the Application of Emotional Intelligence Skills. Management Decision. 49(5), 710-721.

Robb, C. A., \& Woodyard, A. (2011). Financial Knowledge and Best Practice Behavior. Journal of Financial Counseling Planning, 22(1).

Robbins, S. P., \& Judge, T. A. (2009). Organizational Behavior: Pearson.

Rotter, J. B. (1966). Generalized Expectancies for Internal Versus External Control of Reinforcement. Psychological Monographs: General Applied, 80(1), 1.

Salovey, P., \& Mayer, J. D. (1990). Emotional Intelligence. Individual Differences, 9(3), 185-211.

Satterfield, J. M. (1998). Cognitive-Affective States Predict Military and Political Aggression and Risk Taking: a Content Analysis of Churchill, Hitler, Roosevelt, and Stalin. Journal of Conflict Resolution, 42(6), 667-690.

Schjoedt, L., \& Shaver, K. G. (2012). Development and Validation of a Locus of Control Scale for the Entrepreneurship Domain. Small Business Economics, 39(3), 713-726.

Schoemaker, P. J. (1993). Determinants of Risk-Taking: Behavioral and Economic Views. Journal of Risk Uncertainty, 6(1), 49-73.

Sitkin, S. B., \& Weingart, L. R. (1995). Determinants of Risky Decision-Making Behavior: a Test of the Mediating Role of Risk Perceptions and
Propensity. Academy of Management Journal, 38(6), 1573-1592.

Sjöberg, L., \& Engelberg, E. (2009). Attitudes to Economic Risk Taking, Sensation Seeking and Values of Business Students Specializing in Finance. Journal of Behavioral Finance, 10(1), 33-43.

Thompson, E. R. (2009). Individual Entrepreneurial Intent: Construct Clarification and Development of an Internationally Reliable Metric. Entrepreneurship Theory and Practice, 33(3), 669-694.

Vakola, M., Tsaousis, I., \& Nikolaou, I. (2004). The Role of Emotional Intelligence and Personality Variables on Attitudes toward Organisational Change. Journal of Managerial Psychology, 19(2), 88-110.

Van Rooij, M. C., Kool, C. J., \& Prast, H. M. (2007). Risk-Return Preferences in the Pension Domain: are People Able to Choose? Journal of Public Economics, 91(3-4), 701-722.

Vlaev, I., Chater, N., \& Stewart, N. (2009). Dimensionality of Risk Perception: Factors Affecting Consumer Understanding and Evaluation of Financial Risk. Journal of Behavioral Finance, 10(3), 158-181.

Wang, M., Keller, C., \& Siegrist, M. (2011). The Less You Know, the More You are Afraid of-a Survey on Risk Perceptions of Investment Products. Journal of Behavioral Finance, 12(1), 9-19.

Weber, E. U., Blais, A. R., \& Betz, N. E. (2002). A Domain-Specific Risk-Attitude Scale: Measuring Risk Perceptions and Rrisk Behaviors. Journal of Behavioral Decision Making, 15(4), 263-290.

Weber, E. U., \& Milliman, R. A. (1997). Perceived Risk Attitudes: Relating Risk Perception to Risky Choice. Management Science, 43(2), 123-144.

Yip, J. A., \& Côté, S. (2013). The Emotionally Intelligent Decision Maker: Emotion-Understanding Ability Reduces the Effect of Incidental Anxiety on Risk Taking. Psychological Science, 24(1), 48-55. 